\title{
Hubungan Pendapatan dan Status Ketahanan Pangan Rumah Tangga di Wilayah Pesisir di Kecamatan Sidoarjo Kabupaten Sidoarjo (Studi Penelitian di Dusun Kalikajang Kelurahan Gebang)
}

\section{Association between Household Income and Food Security in Coastal Area of Sidoarjo Regency (Reserch Studi In Kalikajang Hamlet, Subdistrict of Gebang)}

\author{
Aisyah Fitria Susanti*1
}

\begin{abstract}
ABSTRAK
Latar Belakang: Ketahanan pangan rumah tangga di wilayah pesisir dapat dilihat dari indikator ketersediaan, akses, pemanfaatan pangan dan stabilitas. Salah satu pilar yang mempengaruhi adalah pendapatan rumah tangga.

Tujuan: Penelitian ini bertujuan untuk menganalisis hubungan antara tingkat pendapatan rumah tangga dengan status ketahanan pangan rumah tangga di wilayah pesisir tambak terisolir di Dusun Kalikajang, Kelurahan Gebang, Kecamatan Sidoarjo, Kabupaten Sidoarjo.

Metode: Jenis penelitian adalah observasional dengan desain cross sectional. Populasi pada penelitian ini yaitu seluruh rumah tangga yang berada di wilayah Dusun Kalikajang Kelurahan Gebang. Teknik penentuan sample menggunakan simple random sampling dengan rumus dari Lemeshow dan didapatkan 52 responden. Data Primer dikumpulkan dengan wawancara dengan kuesioner. Analisis data menggunakan uji statistik Chi Square untuk menguji hubungan antar variabel bebas dan variabel dependen, dan uji regresi logistik untuk menguji adakah hubungan seluruh variabel bebas dengan variabel terikat.

Hasil: Hasil penelitian menunjukkan dari delapan variabel independen yang diujikan, terdapat satu variabel yang berhubungan positif dengan tingkat ketahanan pangan rumah tangga, yaitu pendapatan rumah tangga ( $p$-value $<0.001$ ).

Kesimpulan: Terdapat hubungan yang bermakna antara tingkat pendapatan dengan status ketahanan pangan rumah tangga di wilayah pesisir di Kecamatan Sidoarjo.
\end{abstract}

Kata Kunci: Pendapatan, Ketahanan Pangan Rumah tangga, Regresi Logistik

\section{ABSTRACT}

Background: Household food security in coastal areas can be seen from indicators of availability, access, food utilization and stability. One of the pillars of house hold food security can be influenced by household income.

Objective: This study aimed to analyze the relationship between the level of household income and the status of household food security in isolated coastal areas in Kalikajang Hamlet, Gebang Sub-District, District of Sidoarjo, Sidoarjo Regency.

Method: This type of research was observational study with cross sectional design. The population in this study were all households in the area of Kalikajang Hamlet, Sub-District of Gebang. Sample was determined using simple random sampling technique and using formula from Lemeshow, resulted in 52 respondents included in this study. Primary data was collected through interviews with questionnaires. Data analysis using Chi Square statistical test to test the relationship between independent variables and dependent variables, and logistic regression tests to test whether there is a relationship between all independent variables with the dependent variable.

Results: The results of the study showed that from the eight of independent variables tested, there was one variable that was positively related to the level of household food security, namely household income ( $p$-value $<0.001$ ).

Conclusion: There is a significant relationship between the level of income and the status of household food security in coastal areas in the District of Sidoarjo.

Keywords: Income, Household Food Security, Logistic Regression

*Koresponden:

kuliahaisyah@gmail.com

${ }^{1}$ Departemen Gizi Kesehatan, Fakultas Kesehatan Masyarakat, Universitas Airlangga

Kampus C Mulyorejo, 60115, Surabaya, Jawa Timur, Indonesia 


\section{PENDAHULUAN}

Ketahanan pangan memiliki hubungan yang erat dengan pemenuhan kebutuhan gizi bagi individu dan rumah tangga. Individu atau rumah tangga yang mengalami kekurangan gizi, menandakan rendahnya tingkat konsumsi pangan pada sisi kuantitas maupun kualitas. Hal tersebut dapat terjadi karena berbagai faktor, baik itu pada tingkat persediaan, akses terhadap pangan yang sulit, pemanfaatan bahan pangan yang salah ataupun bahan pangan yang dikonsumsi tidak bernilai gizi baik. Kegagalan mencapai empat indikator tersebut, masih terkait dengan tingginya angka kemiskinan di suatu wilayah. Akses rumah tangga terhadap pangan memiliki hubungan yang erat dengan status kemiskinan.

Menurut Dewan Ketahanan Pangan, Penduduk miskin di Indonesia pada tahun 2014 masih sangat tinggi yaitu sebesar 27,7 juta orang. ${ }^{1} \mathrm{Hal}$ tersebut berimplikasi terhadap banyaknya populasi kekurangan gizi atau malnutrisi di Indonesia. FAO (2017) menyatakan terdapat 20,3 juta penduduk Indonesia yang masih berstatus malnutrisi. ${ }^{2}$

Indonesia merupakan negara agraris dengan luas wilayah lautan sebesar $2 / 3$ dari total luas wilayah negara. Sektor perikanan di Indonesia sangat berpotensi dan memegang peranan penting dalam pembangunan nasional. Sektor perikanan menyediakan kesempatan kerja dan menyediakan sumber pangan berbasis ikan bagi seluruh masyarakat Indonesia. Sektor perikanan di Indonesia, khususnya daerah pesisir memiliki potensi yang cukup besar karena ketersediaan sumber daya alam yang berlimpah.

Namun, daerah pesisir di Indonesia justru merupakan daerah penyumbang kemiskinan terbesar. Menurut Kominfo Jatim (2014), kajian Kementerian Perikanan dan Kelautan menyatakan bahwa jumlah warga miskin di Indonesia didominasi oleh penduduk di wilayah pesisir. Jumlahnya kini mencapai 7,9 juta jiwa atau 25 persen dari total jumlah penduduk miskin di Indonesia. Kemiskinan masyarakat pesisir secara umum disebabkan oleh tidak terpenuhinya hak-hak dasar masyarakat, antara lain kebutuhan akan pangan, kesehatan, pendidikan, pekerjaan dan infrastruktur. Di samping itu, kurangnya kesempatan berusaha, kurangnya akses terhadap informasi, teknologi dan permodalan, budaya dan gaya hidup yang cenderung boros, menyebabkan posisi tawar masyarakat miskin semakin lemah.

Kabupaten Sidoarjo merupakan salah satu daerah di Provinsi Jawa Timur yang memiliki kawasan pesisir. Wilayah pesisir Sidoarjo telah banyak menghasilkan sumber daya perikanan bagi daerah. Wilayah pesisir tersebar disepanjang Kecamatan Waru, Sedati, Buduran, Sidoarjo, Candi, Tanggulangin, Porong dan Krembung. Sebagian besar wilayah pesisir di Sidoarjo digunakan sebagai sentra perikanan air payau atau yang sering disebut tambak. Penduduk di wilayah pesisir sebagian besar bekerja sebagai buruh penjaga tambak dan nelayan ikan tangkap.

Kecamatan Sidoarjo merupakan kecamatan yang juga memiliki wilayah pesisir. Salah satu Dusun yang berada di Kecamatan Sidoarjo adalah Dusun Kalikajang.
Dibanding dengan daerah lain, Dusun Kalikajang dan Pucu'an memiliki akses yang sulit karena ditempuh dengan perjalanan darat dengan kondisi jalan makadam, atau dengan jalur sungai. Dusun ini merupakan satu dari dusun yang terisolir. Jarak dusun Kalikajang dengan Kelurahan Gebang yaitu 15 Kilometer, dan dengan Kecamatan Sidoarjo dan dengan fasilitas pasar terdekat adalah 23 Kilometer. Kebiasaan makan masyrakat di dua dusun tersebut bergantung pada sisa hasil panen tambak, biasanya masyarakat mendapatkan ikan mujair untuk dimakan sehari-hari. Kebutuhan

Keterbatasan akses fisik terhadap pangan sangat memberikan peluang bagi Dusun ini untuk terjadi kerawanan pangan. Namun di sisi lain, Dusun Kalikajang merupakan wilayah pesisir yang memiliki sumber pangan protein hewani berupa ikan dan hasil tambak yang berlimpah. Penelitian ini menfokuskan untuk mengkaji faktor-faktor yang berhubungan dengan ketahanan pangan rumah tangga di Dusun Kalikajang, Kabupaten Sidoarjo.

\section{METODE}

Jenis penelitian adalahobservasional dengan desain penelitian cross sectional. Populasi adalah seluruh rumah tangga di Dusun Kalikajang Kelurahan Gebang, Kecamatan Sidoarjo, Kabupaten Sidoarjo, yang berjumlah satu RW yang terdiri dari 4 RT, RT 13, RT 14, RT 15, dan RT 16 dengan total 105 Kepala Keluarga (KK) dan jumlah penduduk 486 jiwa.

Pengambilan sampel dalam penelitian ini menggunakan teknik Simple Random Sampling. dengan rumus yang digunakan untuk menentukan besar sample adalah rumus Lemeshow. Kriteria inklusi yang ditetapkan diantaranya; penduduk asli Dusun Kalikajang dan menetap di daerah tersebut, berusia produktif yaitu 1564 tahun dan dapat berkomunikasi dengan baik. Kriteria eksklusi untuk penelitian ini diantaranya; penduduk musiman, usia nonproduktif, dan telah pindah rumah. Hasil perhitungan sampel diperoleh besarnya sampel yang didapatkan adalah 52 rumah tangga.

Data yang digunakan adalah data primer. Variabel penelitian terdiri dari satu variabel terikat (dependen) dan delapan variabel bebas (independen). Variabel dependen adalah Ketahanan pangan rumah tangga yang diukur dengan kuesioner terstandar US Household Food Security Survey Module (USHFSSM). Kuesioner USHFSSM diterjemahkan kedalam bahasa Indonesia agar mudah dipahami oleh responden. Setiap jawaban "ya" atau mengonfirmasi keadaan kerawanan pangan rumah tangga diberikan nilai 1 . Pengkategorian skor USHFSSM berdasarkan pada referensi dari USDA $(2012)^{4}$, yaitu tahan pangan (skor 0), rawan pangan dengan derajat kelaparan ringan (skor 1-2), rawan pangan dengan derajat kelaparan sedang (skor 3-7), dan rawan pangan dengan derajat kelaparan berat (skor 818). Selanjutnya, untuk menganalisis variabel ketahanan pangan (variabel dependen) dengan 8 variabel bebas, status ketahanan pangan tersebut dikategorikan menjadi dua, yaitu Tahan Pangan (untuk status tahan pangan dan rawan pangan dengan derajat kelaparan ringan) dan tidak tahan pangan (untuk status rawan pangan dengan derajat kelaparan sedang dan berat). 
Variabel bebas terdiri dari 8 variabel. Variabel pertama adalah karakteristik rumah tangga, dimana yang dikaji adalah pekerjaan kepala rumah tangga, pendidikan pengurus rumah tangga, dalam hal ini adalah Ibu, pendapatan rumah tangga, dan pangsa pengeluaran rumah tangga untuk pangan. Pekerjaan kepala rumah tangga dikaji untuk mengetahui sumber pendapatan rumah tangga. Pendidikan pengurus rumah tangga dapat memengaruhi pengetahuan Ibu mengenai gizi dan dapat memengaruhi perilaku konsumsi makanan di rumah tangga. Klasifikasi tingkat pendidikan didasarkan pada Riskesdas (2013), yaitu tingkat rendah (tamat SD - tamat SMP) dan tingkat tinggi (tamat SMA-perguruan tinggi).

Pendapatan rumah tangga diklasifikasikan berdasarkan klasifikasi BPS (2008) yaitu rumah tangga dengan pendapatan rendah (<Rp. 1.500.000,-), sedang (Rp.1.000.000,- s.d Rp. 2.500.000,-), tinggi (Rp. 2.500.000,- s.d Rp. 3.500.000,-) dan sangat tinggi (>Rp. $3.500 .000,-)$. Pangsa pengeluaran rumah tangga untuk pangan dikaji dengan menanyakan kuesioner pengeluaran dalam satu bulan baik untuk pangan maupun nonpangan. Pangsa pengeluaran pangan didapatkan dari persentase pengeluaran pangan dari pengeluaran total keluarga. Perhitungan pangsa pengeluaran pangan (PF) menggunakan formula berikut:

Dimana:

$$
\mathrm{PF}=\frac{\mathrm{PP}}{\mathrm{TP}} \times 100 \%
$$

$\mathrm{PF}=$ Pangsa atau persentase pengeluaran pangan (\%)

$\mathrm{PP}=$ Pengeluaran untuk belanja pangan ( $\mathrm{Rp} / \mathrm{bulan})$

$\mathrm{TP}=$ Total pengeluaran ( $\mathrm{Rp} /$ bulan $)$

Menurut Jonson dan Toole (1991) dalam Maxwell et al., (2000) ${ }^{5}$ rumah tangga dikatakan tahan pangan bila pangsa pengeluaran untuk pangan kurang dari 60\%. Sebaliknya, rumah tangga tersebut dalam kategori tidak tahan pangan bila pangsa pengeluaran untuk pangan lebih dari sama dengan $60 \%$.

Konsumsi energi dan protein didapatkan dari recall 2x 24 jam, yang dilakukan pada hari kerja (weekday) dan hari libur (weekend) dengan jarak hari yang tidak berurutan, untuk menghindari besarnya dua jenis konsumsi pangan sama dalam waktu yang berurutan. Tingkat konsumsi energi dan protein dikategorikan menurut Dewan Ketahanan Pangan (2009) ${ }^{6}$ yaitu Tidak Tahan Pangan (< 75\% AKG), Cukup Tahan Pangan (75\%-100\% AKG) dan Sangat Tahan Pangan $(\geq 100 \%$ AKG).

Data keragaman pangan didapatkan dari interpretasi recall 24 jam yang diinterpretasikan pada kuesioner Household Diet Diversity Scale (HDDS). Strategi koping rumah tangga diteliti dengan kuesioner Reduced Coping Strategy Index (RCSI).

Analisis data menggunakan uji statistic chi square dan regresi logistik. Analisis chi square digunakan untuk menganalisis frekuensi dan hubungan antar variabel yang berskala data nominal-ordinal. Selanjutnya untuk mengetahui hubungan antar variabel independen dengan variabel dependen digunakan analisis regresi logistik. Pada analisis logistik, variabel dependen skor
USHFSSM di kategorikan menjadi empat kategori sesuai dengan pedoman baku USHFSSM, yaitu tahan pangan, rawan pangan dengan kelaparan ringan, rawan panngan dengan kelaparan sedang dan rawanpangan dengan kelaparan berat ${ }^{7}$. Selanjutnya empat kategori tersebut dimampatkan menjadi dua kategeori, yaitu tahan pangan untuk kategori tahan pangan dan rawan pangan dengan kelaparan ringan, dan tidak tahan pangan untuk kategori rawan pangan dengan kelaparan sedang dan berat. Selanjutnya, variael dependen diujikan dengan 8 variabel independen, Model regresi logistik dinyatakan sebagai berikut:

$$
f(z)=\frac{1}{1+e^{-g(x)}}
$$

dimana untuk analisis multivariate case, untuk mecari $g(x)$ digunakan rumus $^{8}$ :

$$
g(x)=\beta_{0}+\beta_{1} x_{1}+\beta_{2} x_{2}+\cdots+\beta_{i} x_{i}
$$

\section{HASIL DAN PEMBAHASAN}

Tabel 1 menunjukkan hasil penelitian tentang karakteristik rumah tangga berdasarkan pekerjaan kepala rumah tangga, pendidikan pengurus rumah tangga dan pendapatan. Sebagian besar kepala rumah tangga yang bermata pencaharian sebagai buruh tambak atau petani tambak $(89.2 \%)$ berada pada tingkat tidak tahan pangan. Sebagian besar masyarakat Dusun Kalikajang Kecamatan Sidoarjo bermata pencaharian sebagai buruh penjaga tambak, selain itu, mata pencaharian juga ditunjang dengan menjadi petani tambak, yaitu mencari sisa sisa hasil tambak setelah dipanen, lalu sebagian dijual dan sebagian lagi di dikonsumsi oleh rumah tangga.

Jenis pekerjaan berpengaruh signifikan terhadap pendapatan ${ }^{9}$. Pekerjaan sebagai buruh tambak hanya mengandalkan gaji perbulan dari pemilik tambak. Pendapatan tetap yang sedikit, dapat menimbulkan kerawanan pangan pada rumah tangga. Namun, disamping mengandalkan pendapatan dari upah menjaga tambak, juga ditunjang dengan menjadi petani tambak, yaitu mengumpulkan sisa panen tambak untuk dijual kembali dan sebagian dikonsumsi.

Pendidikan pengurus rumah tangga dapat mempengaruhi ketahanan pangan rumah tangga. pendidikan pengurus rumah tangga atau dalam hal ini adalah ibu, mempengaruhi ibu untuk mendapatkan pengetahun mengenai bahan makanan, cara pengolahan makanan dan zat gizi yang dibutuhkan oleh rumah tangga. Dari hasil penelitian, sebagian besar $(84,7 \%)$ berpendidikan rendah (SD-SMP), dan hanya $15,3 \%$ berpendidikan tinggi (SMA). Sementara itu, sebagian besar (90.9\%) Ibu dengan pendidikan rendah berstatus tidak tahan pangan, namun semua ibu yang berpendidikan tinggi juga berstatus tidak tahan pagan. Hal ini meyatakan bahwa pendidikan tidak berhubungan dengan status ketahanan pangan rumah tangga. 
Tabel 1. Hubungan Karakteristik Rumah Tangga dengan Tingkat Ketahanan Pangan Rumah Tangga

\begin{tabular}{|c|c|c|c|c|c|c|c|}
\hline \multirow{3}{*}{ Karakteristik } & \multicolumn{4}{|c|}{ Tingkat Ketahanan Pangan } & \multicolumn{2}{|c|}{ Total } & \multirow{3}{*}{$p$-value } \\
\hline & \multicolumn{2}{|c|}{ Tahan Pangan } & \multicolumn{2}{|c|}{ Tidak Tahan Pangan } & \multirow{2}{*}{$\mathbf{N}$} & \multirow{2}{*}{$\%$} & \\
\hline & $\mathrm{n}$ & $\%$ & $n$ & $\%$ & & & \\
\hline \multicolumn{8}{|c|}{ Pekerjaan Kepala Rumah tangga } \\
\hline Pedagang & 0 & 0 & 5 & 9.7 & 5 & 9.7 & \multirow{5}{*}{$p=0.624$} \\
\hline Buruh atau petani & 4 & 7.7 & 33 & 63.4 & 37 & 71.1 & \\
\hline Wiraswasta & 0 & 0 & 2 & 3.9 & 2 & 3.9 & \\
\hline Nelayan & 0 & 0 & 8 & 15.3 & 8 & 15.3 & \\
\hline Total & & & & & 52 & 100 & \\
\hline \multicolumn{8}{|l|}{ Pendidikan } \\
\hline $\begin{array}{l}\text { Rendah } \\
\text { (SD-SMP) }\end{array}$ & 4 & 7.7 & 40 & 77 & 44 & 84.7 & \multirow{3}{*}{$p=0.624$} \\
\hline $\begin{array}{l}\text { Tinggi } \\
\text { (SMA-Perguruan Tinggi) }\end{array}$ & 0 & 0 & 8 & 15.3 & 8 & 15.3 & \\
\hline Total & & & & & 52 & 100 & \\
\hline \multicolumn{8}{|l|}{ Pendapatan Rumah Tangga } \\
\hline $\begin{array}{l}\text { Rendah } \\
(<1.500 .000)\end{array}$ & 0 & 0 & 10 & 19.2 & 10 & 19.2 & \multirow{4}{*}{$p<0.001$} \\
\hline $\begin{array}{l}\text { Sedang } \\
(1.500 .000-2.500 .000)\end{array}$ & 2 & 3.9 & 37 & 71.1 & 39 & 75 & \\
\hline $\begin{array}{l}\text { Tinggi } \\
(2.500 .000-3.500 .000)\end{array}$ & 2 & 3.9 & 1 & 1.9 & 3 & 5.8 & \\
\hline Total & & & & & 52 & 100 & \\
\hline \multicolumn{8}{|l|}{ Pangsa Pengeluaran Pangan } \\
\hline$\geq 60 \%$ & 0 & 0 & 3 & 5.8 & 3 & 5.8 & \multirow{3}{*}{$p=0.624$} \\
\hline$<60 \%$ & 3 & 5.8 & 46 & 88.4 & 49 & 94.2 & \\
\hline Total & & & & & 52 & 100 & \\
\hline
\end{tabular}

Tabel 2. Hubungan Karakteristik Rumah Tangga dengan Tingkat Ketahanan Pangan Rumah Tangga

\begin{tabular}{|c|c|c|c|c|c|c|c|c|}
\hline \multirow{3}{*}{$\begin{array}{l}\text { Tingkat } \\
\text { (HDDS) }\end{array}$} & \multirow{3}{*}{ Pangan } & \multicolumn{4}{|c|}{ Tingkat Ketahanan Pangan } & \multicolumn{2}{|c|}{ Total } & \multirow{3}{*}{$p$-value } \\
\hline & & \multicolumn{2}{|c|}{ Tahan Pangan } & \multicolumn{2}{|c|}{ Tidak Tahan Pangan } & \multirow{2}{*}{$N$} & \multirow{2}{*}{$\%$} & \\
\hline & & $n$ & $\%$ & $n$ & $\%$ & & & \\
\hline $\begin{array}{l}\text { Rendah } \\
\text { ( } \leq 3 \text { bahan pangan) }\end{array}$ & & 0 & 0 & 12 & 23.1 & 12 & 23.1 & \\
\hline $\begin{array}{l}\text { Sedang } \\
\text { (4-5 bahan pangan }\end{array}$ & & 4 & 5.8 & 31 & 59.6 & 34 & 65.4 & $p=0.419$ \\
\hline $\begin{array}{l}\text { Tinggi } \\
\text { ( } \geq 6 \text { bahan pangan) }\end{array}$ & & 1 & 1.9 & 5 & 9.6 & 2 & 11.5 & \\
\hline Total & & & & & & 52 & 100 & \\
\hline
\end{tabular}

Tabel 3. Hubungan coping strategy dengan tingkat ketahanan pangan

\begin{tabular}{|c|c|c|c|c|c|c|c|}
\hline \multirow{3}{*}{ Coping Strategy } & \multicolumn{4}{|c|}{ Status Ketahanan Pangan } & \multicolumn{2}{|c|}{ Total } & \multirow{3}{*}{$p$-value } \\
\hline & \multicolumn{2}{|c|}{ Tahan Pangan } & \multicolumn{2}{|c|}{ Tidak Tahan Pangan } & \multirow{2}{*}{$N$} & \multirow{2}{*}{$\%$} & \\
\hline & $\mathbf{n}$ & $\%$ & $\mathbf{n}$ & $\%$ & & & \\
\hline $\begin{array}{l}\text { No or low coping } \\
\text { (CSI 0-3) }\end{array}$ & 0 & 0 & 6 & 11.6 & 6 & 11.6 & \\
\hline $\begin{array}{l}\text { Medium } \\
\text { (CSI 4-9) }\end{array}$ & 4 & 7.7 & 34 & 65.38 & 38 & 73.02 & $p=0.624$ \\
\hline $\begin{array}{l}\text { High coping } \\
\text { (CSI } \geq 10)\end{array}$ & 0 & 0 & 8 & 15.3 & 8 & 15.3 & \\
\hline Total & & & & & 52 & 100 & \\
\hline
\end{tabular}


Tabel 4. Analisis Regresi Logistik Variabel-variabel Yang Mempengaruhi Ketahanan Pangan Rumah Tangga

\begin{tabular}{|c|c|c|c|c|}
\hline \multirow{2}{*}{ Variabel bebas } & \multirow{2}{*}{ Sig. } & \multirow{2}{*}{ Exp. (B) } & \multicolumn{2}{|c|}{ 95\% Confidence Interval } \\
\hline & & & Upper & Lower \\
\hline Pekerjaan Kepala Keluarga $\left(\mathrm{X}_{1}\right)$ & 0.269 & & & \\
\hline Pendidikan Pengurus Rumah Tangga $\left(\mathrm{X}_{2}\right)$ & 0.424 & 0.168 & 0.002 & 13.34 \\
\hline $\begin{array}{l}\text { Pendapatan rumah tangga }\left(X_{3}\right)(0=\text { Rendah; } \\
1=\text { sedang; } 2 \text { = tinggi) }\end{array}$ & $<0.001$ & 0.67 & 0.16 & 0.279 \\
\hline $\begin{array}{l}\text { Pangsa Pengelauaran Rumah Tangga } \\
\text { untuk Pangan }\left(\mathrm{X}_{4}\right)\end{array}$ & 0.9 & 0.00 & 0.00 & \\
\hline Keragaman Pangan (HDDS) $\left(\mathrm{X}_{5}\right)$ & 0.9 & & & \\
\hline Tingkat Konsumsi Energy $\left(\left(\mathrm{X}_{6}\right)\right.$ & 0.219 & 0.229 & 0.022 & 2.410 \\
\hline Tingkat Kecukupan Protein $\left(\mathrm{X}_{7}\right)$ & 0.78 & 1.004 & 0.978 & 1.030 \\
\hline Coping Strategy $\left(\mathrm{X}_{8}\right)$. & 0.9 & & & \\
\hline
\end{tabular}

Pada analisis pendapatan rumah tangga dengan tingkat ketahanan pangan, didapatkan hasil bahwa sebagian besar responden berpendapatan sedang yaitu berkisar antara 1.500 .000 sampai dengan 2.500.000. Pada kondisi tersebut sebagian besar (94.9\%) rumah tangga dengan pendapatan tersebut berstatus tidak tahan pangan.

Rendahnya tingkat pendidikan dan didukung oleh penghasilan yang rendah, akan berpengaruh berpengaruh terhadap kebiasaan makan sehari- hari. Definisi makan bagi kelompok seperti ini bukanlah yang sehat dan bergizi, teetapi lebih kepada makan makanan yang mengenyangkan tanpa melihat nilai gizi dari makanan tersebut. Hal tersebut diduga dapat menjadi faktor risiko terjadinya rawan pangan. ${ }^{10}$

Pangsa pengeluaran pangan rumah tangga adalah rasio antara pengeluaran pangan dengan pengeluaran total rumah tangga perbulan. Jika pangsa pengeluaran $<60 \%$ maka rumah tangga tersebut tahan pangan, tetapi jika pangsa pengeluaran pangan $\geq 60 \%$ maka rumah tangga tersebut rawan pangan. ${ }^{5}$ Pada penelitian ini didapatkan sebagian besar pangsa pengeluaran rumah tangga responden < 60\% (93.9), yang berarti responden berada pada posisi tahan pangan menurut perhitungan pangsa pengeluaran rumah tangga. Semakin rendah pangsa pengeluaran pasar, maka rumah tangga akan semakin tahan pangan.

Namun, ketahanan pangan dapat saja tidak dipengaruhi oleh pangsa pengeluaran pangan rumah tangga. Pangsa pengeluaran, ketahanan pangan di pengaruhi oleh faktor lain, diantaranya adalah tingkat pendapatan, harga bahan pokok, jumlah tanggungan keluarga, tingkat pendidikan, pengetahuan gizi, konsumsi akan protein hewani dan nabati serta lingkungan tempat tinggal. ${ }^{11}$

Pada penelitian ini, rata-rata jumlah pengeluaran pangan responden perbulan lebih kecil dibandingkan jumlah pengeluaran non pangan. Jumlah pengeluaran pangan yaitu $\mathrm{Rp} 639.461$,- dengan rata-rata pengeluaran terbesar untuk konsumsi beras sebesar Rp. 205.171. Pengeluaran non pangan tertinggi yaitu untuk membeli rokok Rp 535.485,- (67\%), dan untuk membayar iuran bulanan (arisan, hutang, dan iuran sosial) (25\%) dan untuk keperluan sekolah (8\%). Hal tersebut menunjukkan bahwa rokok memiliki beban terbesar dalam pengeluaran rumah tangga.

Pada rumah tangga dengan menengah kebawah, konsumsi rokok dapat memakan beban paling berat untuk pengeluaran rumah tangga setiap bulannya. Hal ini dapat disebabkan oleh rendahnya pendidikan sehingga pengetahuan rumah tangga terhadap kesehatan dan bahaya merokok masih rendah. Perilaku merokok ditemukan berbanding terbalik dengan tingkat pendidikan, semakin rendah tingkat pendidikan seseorang, maka semakin besar peluang orang tersebut menjadi perokok. ${ }^{12}$

Pengeluaran rumah tangga untuk rokok dapat dipengaruhi oleh pendapatan, pengeluaran rumah tangga untuk pangan, biaya pendidikan dan biaya kesehatan. ${ }^{13}$ Pada penelitian di Dusun Kalikajang ini, sebagian besar rumah tangga mendapatkan bantuan ppemerintah untuk menunjang pengeluaran rumah tangga untuk pangan (BPNT), biaya pendidikan (PIP) dan kesehatan (KIS), sehingga memungkinkan untuk meningkatkan pengeluaran rumah tangga untuk rokok. Rata-rata keragaman pangan rumah tangga berada pada tingkat sedang (skor HDDS 4). Pada tingkatkeragaman pangan sedang, sebagian besar rumah tangga berstatus tidak tahan pangan (89.2\%). Rumah tangga di Dusun Kalikajang sebagian besar megonsumsi beras sebagai makanan pokok. Sebagian besar rumah tangga mendapatkan bantuan dari pemerintah untuk kebutuhan pokok tersebut, namun untuk mencukupi, rata-rata rumah tangga masih membeli beras tambahan untuk mencukupi kebutuhan setiap bulan.

Rata-rata rumah tangga sudah mengonsumsi sumber protein hewani, namun jika dilihat dari kecukupan protein yang dikonsumsi setiap hari, sebagian besar rumah tangga mengonsumsi sumber protein kurang dari AKG. Hal tersebut juga didapatkan pada kecukupan konsumsi energi rumah tangga, sebagian besar juga masih pada kategori kurang dari AKG.

Penghitungan konsumsi energi dan protein juga dilakukan pada rumah tangga. Rata-rata konsumsi energi sebesar 1140,26 kkal/hari dengan konsumsi terendah adalah $700,95 \mathrm{kkal} / \mathrm{hari}$ dan konsumsi energi tertinggi 
1396,1 kkal/hari, dengan standar deviasi 160,97. Sedangkan rata-rata konsumsi protein rumah tangga yaitu $47 \mathrm{~g} / \mathrm{hr}$ dengan konsumsi terendah yaitu 30,80 $\mathrm{g} / \mathrm{hr}$ dan tertinggi $73.25 \mathrm{~g} / \mathrm{hari}$, dengan standar deviasi 8.95. Angka kecukupan energi dan protein untuk masyarakat Indonesia yaitu $2200 \mathrm{kkal} / \mathrm{hari}$ dan 57 $\mathrm{g} /$ hari. Sedangkan menurut Sedangkan menurut Dewan Ketahanan Pangan (2009), tingkat kecukupan energi dan protein dapat digolongnkan menjadi tidak tahan pangan (TKE < 75\% AKE), cukup tahan pangan (TKE 75-100\% AKE) dan sangat tahan pangan (TKE $\geq 100 \%$ AKE). ${ }^{14}$ Tingkat kecukupan protein juga memiliki standar yang sama dengan tingkat kecukupan energy. Dilihat dari standar tersebut, seluruh rumah tangga (100\%) di wilayah pesisir masih mengalami kondisi tidak tahan pangan $(<75 \%$ AKE). Sedangkan $63,5 \%$ rumah tangga berstatatus cukup tahan pangan, sedangkan $25 \%$ rumah tangga berstatus tidak tahan pangan dan $11,5 \%$ berstatus tahan pangan.

Bila dilihat dari dekatnya akses rumah tangga terhadap sumber protein hewani yaitu berbagai macam hasil tambak seperti ikan dan udang, ditambah dengan aktifitas bertani tambak dan mengumpulkan sisa panen tambak, seharusnya rumah tangga yang tinggal di wilayah tersebut dapat mencukupi kebutuhan protein dari hasil tambak tersebut. Namun hal tersebut belum terjadi pada rumah tangga di Dusun Kalikajang. Hal tersebut dapat terjadi karena hanya sebagian kecil sisa hasil tambak yang dikonsumsi, dan sebagain besar lainnya dijual untuk menambah pendapatan. asil penelitian menunjukkan bahwa sebanyak 39 rumah tangga (73.1\%) berada pada tingkat medium (skor 4-9). Semakin besar skor rumah tangga tersebut maka menunjukkan keadaan semakin tidak tahan pangan. Uji statistik menunjukkan bahwa tidak ada hubungan yang signifikan antara coping strategy dan tingkat ketahanan pangan. Sehingga dapat dikatakan, tidak ada hubungan antara strategi koping yang dilakukan oleh rumah tangga di wilayah pesisir Kecamatan Sidoarjo dengan status ketahanan pangannya.

Berdasarkan hasil uji statistik regresi logistik tersebut, dari delapan variabel independen, dinyatakan bahwa variabel yang berpengaruh signifikan dengan taraf kepercayaan 95 persen $(p<0,05)$ pada tingkat ketahanan pangan rumah tangga adalah dummy $\left(\mathrm{X}_{3}\right)$ pendapatan rumah tangga sedang (Rp.1.500.000,sampai dengan Rp. 2.500.000,-). Oleh karena itu, persamaan regresi logistik akhir yang akan digunakan dalam penelitian ini adalah sebagai berikut:

$$
\begin{gathered}
g(x)=-2708 x \text { pendapatansedang } \\
f(z)=\frac{1}{1+e^{-g(x)}} \\
f(z)=\frac{1}{1+e^{-(-2708 x \text { pendapatansedang })}}
\end{gathered}
$$

Nilai odds ratio pada regresi logistik didapatkan dari nilai Exp (B). Nilai Exp (B) untuk variabel dummy pendapatan rumah tangga adalah 0.67 dengan 95\% confidence interval 0.16-0.279. Untuk memudahkan penginterpretasian nilai odds ratio, maka nilai tersebut dijadikan persamaan $1 / 0.67$, sehingga mendapatkan hasil akhir odds ratio dari dummy pendapatan sedang adalah 1,5.
Penginterpretasian nilai odds ratio tersebut di balik, dengan begitu dapat diartikan bahwa rumah tangga yang memiliki pendapatan sedang (Rp. 1.500.000,- sampai dengan 2.500.000,-) lebih besar kemungkinan 1,5 kali untuk tidak mengalami kerawanan pangan ${ }^{15}$. Hubungan yang positif menunjukkan bahwa dengan semakin meningkatnya pendapatan rumah tangga maka tingkat ketahanan pangan rumah tangga akan semakin baik. Hal ini terutama terkait dengan faktor daya beli rumah tangga.

Semakin banyak kepala rumah tangga terlibat dalam pekerjaan yang menguntungkan, semakin tinggi ia mendapatkan penghasilan dan semakin besar peluang untuk mendapatkan makanan yang terjamin. Pendapatan tersebut diharapkan dapat meningkatkan produksi makanan rumah tangga dan akses ke lebih banyak kuantitas dan kualitas makanan yang lebih baik. Karena itu, efek yang diharapkan pada keamanan keamanan pangan adalah positif. ${ }^{16}$

Kemampuan rumah tangga untuk mendapatkan pangan merupakan faktor yang penting dan paling kritis dalam menentukan tingkat ketahanan pangan rumah tangga. Faktor lain yang sangat penting adalah daya beli masyarakat untuk memenuhi konsumsi yang memenuhi syarat gizi seperti energi dan protein. Namun, sebagian masyarakat kita masih kurang kalori dan protein karena daya beli yang rendah. ${ }^{17}$

\section{KESIMPULAN}

Kesimpulan dari penelitian ini adalah terdapat hubungan yang positif antara tingkat pendapatan dengan tingkat ketahanan pangan rumah tangga di wilayah pesisir di Kecamatan Sidoarjo, Kabupaten Sidoarjo. Pendapatan rumah tangga di wilayah tersebut sebagian besar berasal dari pekerjaan menjadi buruh tambak dan petani tambak. Proporsi pengeluaran pangan untuk pendapatan perlu ditingkatkan sehubungan dengan masih rendahnya konsumsi energi dan protein rumah tangga di wilayah tersebut.

\section{ACKNOWLEDGEMENT}

Terima kasih kepada Perangkat Kelurahan Gebang, dan para tokoh masyarakat Dusun Kalikajang yang telah membantu dalam proses penelitian.

\section{REFERENS}

1. World Food Programme; Dewan Ketahanan Pangan; Kementerian Pertanian; Peta Ketahanan dan Kerentanan Pangan INDONESIA 2015. 121 (2015). doi:WFP276267

2. Food and Agriculture Organization of the United Nations. The State of Food Security and Nutrition in the World. Fao (2017).

3. Jatim, K. Warga Miskin Didominasi Wilayah Pesisir. http://kominfo.jatimprov.go.id/read/umum/399 80 (2014). Available at: http://kominfo.jatimprov.go.id/read/umum/399 80. 
4. USDA. U.S. Household Food Security Survey Module: Three-stage Design, with Screeners. 1, (2012).

5. Maxwell. Daniel, et al. Urban Livelihoods And Food And Nutrition Security In Greater Accra, Ghana. Research Report (2000).

6. Dewan Ketahanan Pangan. Indonesia Tahan Pangan Dan Gizi 2015. (Kementerian Pertanian $\mathrm{RI}, 2009)$.

7. Do, D. et al. Advances in Developing Country Food Insecurity Measurement Measuring Household Food Insecurity: Why It ' $s$ So Important and Yet So. 1404-1408 (2006).

8. Ghozali, I. Aplikasi Analisis Multivariate dengan Program IBM SPSS 23. (BPFE Universitas Diponegoro, 2016).

9. Pertiwi, P. Analisis Faktor yang Mempengaruhi Pendapatan Tenaga Kerja di Daerah Istimewa Yogyakarta. (Universitas Negeri Yogyakarta, 2015).

10. Baliwati, Yayuk Farida, Dodik Briawan, V. M. Pengembangan Instrumen Penilaian Kualitas Konsumsi Pangan pada Rumah Tangga Miskin di Indonesia. J. Gizi Indones. 38, 63-72 (2015).

11. Rachmah, M. A. Analisis Faktor-Faktor yang Mempengaruhi Pangsa Pengeluaran Pangan Rumah Tangga Petani di Kecamatan Suruh Kabupaten Semarang. J. Pangan dan Gizi 7, (2017).

12. Sugiharti, L., Sukartini, N. M. \& Handriana, T. Konsumsi Rokok Berdasarkan Karakteristik
Individu di Indonesia. J. Ekon. Kuantitatif Terap. 8, 34-45 (2015).

13. Sari, H., Syahnur, S. \& Seftarita, C. Faktor-Faktor yang Mempengaruhi Pengeluaran Konsumsi Rokok pada Rumah Tangga Miskin di Provinsi Aceh. J. Perspekt. Ekon. Darussalam 3, 117-133 (2017).

14. Dewan Ketahanan Pangan. Kebijakan Strategis Pangan dan Gizi: Tahun 2015-2019. (Kementerian Pertanian Rl, 2015). http://bkp.pertanian.go.id/storage/app/media/i nformasi\%20publik/Pedoman/KSPG_20152019(2).pdf

15. Wibowo, Arief, Soenartalina, Rachmah Indawati, Mahmudhah, D. I. Modul SPSS. (Fakultas Kesehatan Masyarakat Universitas Airlangga, 2016).

16. John, K. M. K., Demi, M. S. \& Ditchfield, P. K. A. Comparative Analysis of Food Security Status of Farming Households in the Costal and the Forest Communities of Central Region of Ghana. Asian J. Empir. Res 3(1), 39-61 (2013).

17. Rusyantia, A., Haryono, D. \& Kasymir, E. Kajian Ketahanan Pangan Rumah tangga Pedesaan Dalam Upaya Peningkatan Status Gizi Masyarakat di Kabupaten Lampung Selatan Household Food Security Assessment in Rural Communities Improving Nutritional Status in South Lampung regency. J. Penelit. Pertan. Terap. 10, 171-184 (2010). 